\title{
Utilization of Dietary Soybean Meal and Groundnut Meal as Fish Meal Replacement in Heteropnuestes fossilis (Bloch.)
}

\author{
Archit Shukla ${ }^{1}$, Vaneet Inder Kaur ${ }^{1}$, Pankaj Kumar ${ }^{2 *}$, Meera D. Ansal ${ }^{1}$, \\ Asha Dhawan ${ }^{1}$ and Varun Mishra ${ }^{3}$ \\ ${ }^{1}$ Department of Aquaculture, College of Fisheries, Guru Angad Dev Veterinary and Animal \\ Sciences University (GADVADU), Ludhiana - 141004, Punjab, India \\ ${ }^{2}$ ICAR-Central Institute of Fisheries Education, Rohtak Centre, \\ Lahli (124411) Haryana, India \\ ${ }^{3}$ College of Fisheries, MPUAT Udaipur (313001), Rajasthan, India \\ *Corresponding author
}

\section{A B S T R A C T}

\begin{tabular}{|l|}
\hline Ke y w or d s \\
$\begin{array}{l}\text { Heteropnuestes fossilis } \\
\text { (Bloch), Cattish feeding, } \\
\text { Fish meal, Sobyean meal, } \\
\text { Groundnut meal }\end{array}$ \\
\hline Article Info \\
\hline $\begin{array}{l}\text { Accepted: } \\
\text { 04 May } 2018 \\
\text { Available Online: } \\
\text { 10 June 2018 }\end{array}$ \\
\hline \hline
\end{tabular}

Soybean meal (SBM) and groundnut meal (GNM) incorporated diets were evaluated as replacement of fish meal for rearing of fingerlings of catfish, Heteropnuestes fossilis (Bloch.) for a period of 150 days. Fish meal in the control diet $\left(D_{1}\right)$ was replaced with SBM and GNM at $50 \%$ level $\left(\mathrm{D}_{4}\right.$ and $\left.\mathrm{D}_{5}\right)$ and $100 \%$ level $\left(\mathrm{D}_{2}\right.$ and $\left.\mathrm{D}_{3}\right)$ respectively, whereas in diet $\mathrm{D}_{6}, \mathrm{SBM}$ and GNM (1:1) replaced $100 \%$ of fish meal. $\mathrm{D}_{7}$ diet also prepared having only rice bran and mustard meal (1:1). Results showed that SBM and GNM incorporated diets had no significant effect on the physico-chemical parameters of the water. Highest growth rate in terms of average final body weight, PER, SGR and condition factor was observed in diet $\mathrm{D}_{2}$ and lowest in diet $\mathrm{D}_{6}$. Similarly lowest FCR and maximum net profit was recorded in the group fed diet $\mathrm{D}_{2}$. In the present study it has been seen that fish meal can be completely replaced with Soybean meal $\left(\mathrm{D}_{2}\right)$ without hampering growth, hence can be used for formulating nutritionally balanced diet for $H$. fossilis (Bloch.).

\section{Introduction}

Heteropneustes fossilis (Bloch.) commonly known as Singhi or stinging catfish, is considered as one of the highly demanded freshwater air breathing fish species in the Indian subcontinent and Southeast Asian region. Heteropneustes fossilis has got ability to acclimatize in fresh and brackish water both with varying concentration of oxygen level and can be withstand under poor environmental conditions (Pillay, 2001). Furthermore, it is being hardiest fish (Dehadrai, 1978) and fetch higher price due to higher digestibility, palatability, medicinal and nutritive value. It can be cultured under monoculture as well as poly-culture systems (Haniffa, 2009).

Quality and quantity of the feed ingredients play an effective role in formulation of balanced formulated feed as it accounts for 
more than $60 \%$ of total input cost (Sharma et al., 2001). Fish meal is one of the most commonly used major aquatic animal protein source for preparation of traditional formulated aqua feeds but it's usage has fallen gradually since 2006 (4.23 mt in 2005 to 3.72 $\mathrm{mt}$ in 2008) which will decrease further to $3.63 \mathrm{mt}$ by 2015 and to $3.49 \mathrm{mt}$ by 2020 (FAO, 2012). Utilization of fish meal in aqua feed has been decreased due to factors like reduced supply, high cost, adulteration/poor quality and increase use of more cost effective plant and animal based feed ingredients in place of fish meal. This has necessitates the search for replacement of fishmeal with other high quality and locally available plant protein ingredients like soybean meal, groundnut meal etc. to formulate a cost effective nutritionally balanced aquaculture diet especially for catfish (Khan and Jafri, 1990; Robinson et al., 2006; Dhawan and Kaur, 2007; Robinson and Li, 2007).

Soybean meal (SBM) is the product obtained after oil extraction, having crude protein levels of 44-48 \% (NRC, 1993). The amino acid composition of SBM represents the most balanced profile of all plant proteins having more than $90 \%$ digestibility in various freshwater omnivorous fish species. Several experiments revealed that the diets containing 28-32\% crude protein primarily from SBM provide growth equivalent to diets containing animal protein such as fish meal and meat and bone meal (Robinson and Li, 1999; Robinson et al., 2000; Li et al., 2000) without requiring supplementation of any crystalline amino acids. The main limitation of soybean use as fish feed can be related to the low level of methionine and the presence of anti-nutritional factors (Ollie et al., 1994). Likewise groundnut meal can also be considered as one of the important plant based protein supplement for promoting growth in fish. It is highly palatable and has better binding properties for pelleting than soybean (Lovell,
1989). It is a valuable source of vitamin B, E and K. Groundnut protein (GNP) is also deficient in methionine, cystine and lysine, but amino acid quality can be improved in formulated diets, either by enrichment with deficient amino acids (Eyo and Olatunde, 1998), or addition of other protein sources (Ovie and Ovie, 2007).

Keeping this in view to availability of quality as well quantity of fish meal, the present study was designed to assess the comparative efficacy of plant protein resources (SBM and GNM) as substitutes for replacement of fish meal in catfish (H. fossilis) diet and to study the effect of these diets on physico-chemical parameters of water, survival and growth of fingerlings of $H$. fossilis.

\section{Materials and Methods}

\section{Experimental design and set-up}

The study was conducted at the fish farm of College of Fisheries, Guru Angad Dev Veterinary and Animal Sciences University, Ludhiana (Punjab), India. The growth of fish was assessed with relation to different formulated diets over a period of 150 days. The study was conducted in FRP pools (1.50 $\mathrm{m} \times 1.0 \mathrm{~m} \times 1.0 \mathrm{~m})$ in triplicate. Each cistern was stocked with 10 fingerlings (average length $10.52-10.88 \mathrm{~cm}$, average weight 8.16 $8.90 \mathrm{~g}$ ) of Heteropnuestes fossilis.

\section{Diet formulation and preparation}

Total seven experimental supplementary diets were formulated (Table 1). Diet $\mathrm{D}_{1}$ was control diet (fish meal based diet) and five diets $\left(D_{2}-D_{6}\right)$ were formulated by partial and full replacement of fish meal with SBM and GNM whereas diet $D_{7}$ was traditional feed used by the farmers for carp farming (rice bran 1: mustard meal 1). For the preparation of diets, required ingredients were grounded, 
mixed, steam cooked and provided to fish in the pelleted form. Proximate composition of feed ingredients and formulated diets (Table 2) was determined following the standard methods of AOAC (2005).

\section{Feeding schedule}

Feed was given at $5 \%$ of the body weight for 150 days, twice in day at 8:00 and 18:00 h under normal light regime (light/dark: 12/12h). The feed quantity was regulated based on the fortnightly sampling of all the fingerlings from each treatment.

\section{Physico-chemical parameters of water}

Throughout the study period physicochemical parameters of water samples i.e. temperature, $\mathrm{pH}$, dissolved oxygen, total alkalinity, Hardness, $\mathrm{NH}_{3}-\mathrm{N}, \mathrm{NO}_{3}-\mathrm{N}, \mathrm{NO}_{2}-\mathrm{N}$ and $\mathrm{PO}_{4}-\mathrm{P}$ were measured at fortnightly intervals following standard methods (APHA, 1991).

\section{Growth study}

Fish were measured in terms of weight gain by using analytical balances with precision of $0.01 \mathrm{~g}$ at fortnightly intervals

Weight gain \% (WG) $=100$ (final weightinitial weight)/initial weight

Specific growth rate $(\mathrm{SGR})=100$ (ln final weight-ln initial weight)/ no. of days of feeding trial)

Feed conversion ratio $(\mathrm{FCR})=$ Feed Intake/Weight Gain

Protein efficiency ratio $(\mathrm{PER})=$ total wet weight gain $(\mathrm{g}) /$ crude protein fed $(\mathrm{g})$

Fulton's condition factor (K): Fulton's condition factor $(\mathrm{K})$ was calculated according to Htun-Han (1978) equation as per formula given below:

$\mathrm{K}=\frac{\mathrm{W} \times 100}{\mathrm{~L} 3}$

Where, W=weight of fish (g), L=Length of fish $(\mathrm{cm})$.

\section{Statistical analysis}

The data were statistically analyzed by Statistical Package for the Social Sciences (SPSS) version 16. Comparison between two treatments was made using Duncan's Multiple Range Test (DMRT). Comparison among all the treatment was done by one way ANOVA. Comparisons were made at the $5 \%$ probability levels. Dandrogram studies were conducted through PAST, SPSS and PRIMER software.

\section{Results and Discussion}

\section{Physico-chemical parameters}

There were no significant difference observed in water quality parameters viz. temperature, $\mathrm{pH}$, dissolved oxygen, total alkalinity, Hardness, $\mathrm{NH}_{3}-\mathrm{N}, \mathrm{NO}_{3}-\mathrm{N}, \mathrm{NO}_{2}-\mathrm{N}$ and $\mathrm{PO}_{4}-\mathrm{P}$ (Table 3) in among different treatment groups and they were within the range as suggested by Boyd and Pillai (1984); Rowland (1986) and Boyd and Tucker (1998).

The overall variation in physico-chemical parameters of water in present study are also represented through cluster analysis of log transformed correlation matrix (Fig. 1a-1g). In $\mathrm{D}_{1}, \mathrm{D}_{2}, \mathrm{D}_{5}$ and $\mathrm{D}_{7}$ mainly 2 clusters are formed. The cumulative effect of parameters is positive except nitrite, which creates negative cumulative effect with rest of the parameters. Likewise in $\mathrm{D}_{4}, 2$ clusters are formed, but the cumulative effect of the parameters is negative. In $\mathrm{D}_{3}, 3$ clusters are formed and the overall cumulative effect of 
water quality parameters is also negative. In case of $\mathrm{D}_{6}$, there are 2 main clusters formed and the cumulative effect of water quality parameters is positive.

Brett (1979), suggested that growth, feed efficacy, feed consumption and overall wellbeing of the fish depend upon various environmental factors, which in turn depend upon various physico- chemical parameters of water (Rahman et al., 1982). Results of present experiment showed that all the water quality parameters were within the range for fish culture. Moreover the values for all the parameters did not differed significantly among the treatments, which further strengthen the fact the use of plant protein sources as an alternative for fish meal has no negative effect in term of water quality.

\section{Growth parameters}

At the end of culture period, the average body weight, \% WG, SGR and PER was found to be highest $(23.92 \mathrm{~g}, 15.05 \mathrm{~g}, 169.67 \%, 0.66$ and 0.32) in diet $\mathrm{D}_{2}$ and lowest (15.88 g, 7.33 g, 85.73\%, 0.41 and 0.15$)$ in diet $\mathrm{D}_{6}$. Similarly, minimum FCR value was reported from diet $\mathrm{D}_{2}$, showing the better conversion efficiency of diet. There was significant difference reported in among the treatment groups for all the growth parameters.

The studies revealed that the growth of fingerlings of $H$. fossilis (Bloch.) was maximum in diet $\mathrm{D}_{2}(100 \%$ of fish meal was replaced with $\mathrm{SBM}$ ), followed by diet $\mathrm{D}_{4}$ (50\% of fish meal was replaced with SBM), diet $\mathrm{D}_{5}$, $(50 \%$ of fish meal was replaced with GNM), Diet $\mathrm{D}_{7}$ (traditional carp diet having rice bran and mustard meal in equal ratio) and diet $\mathrm{D}_{1}$ (control diet) having fish meal. Diet $\mathrm{D}_{3}$ (100\% fish meal was replaced with GNM) and diet $\mathrm{D}_{6}(100 \%$ fish meal was replaced with mixture of SBM and GNM), showed minimum growth.
In the present study, it has been observed that acceptability of soybean meal (SBM) up to a certain level in place of fish meal. Hence, it can be attributed to higher digestibility which is supported by Lim and Akiyama (1992), reported more than $90 \%$ digestibility of SBM in common carp, channel catfish, tilapia etc.

Furthermore, in channel catfish, studies have revealed that if complete replacement of fish meal was done with SBM or other ingredients such as cotton seed meal or meat cum bone meal, no impairment was observed in growth and feed efficiency (Reigh, 1999; Li et al., 2000). However, Nyirendea et al., (2000) used SBM as sole protein source in the diets of Oreochromis karongae and obtained higher growth rate in term of SGR, FCR as well as fish yield.

Goda et al., (2007) observed, total and partial replacement of fish meal in African catfish, Clarias gariepinues with SBM @ 75\% and $100 \%$ resulted in higher final body weight and SGR, but differences from control were nonsignificant. According to Webster et al., (1992) and Kaushik et al., (1995) substituting fish meal with soy protein in diets given to catfish did not adversely affect feed intake.

The acceptability of SBM at $100 \%$ and $50 \%$ level in present studies also demonstrate its utilization by $H$. fossilis without any deteriorating effect. Bhilave et al., (2012) used different soybean formulated diets, which resulted in best PER in 100\% soybean diets in grass carp, Ctenopharyngodon idella.

However, in some of the studies carried out with fish species like young channel catfish ( $I$. punctatus) and Indian magur (C. batrachus), $100 \%$ replacement of fish meal with SBM does not give encouraging results (Mohsen and Lovell, 1990; Dhawan and Kaur, 2007), which had been attributed to the presence of antinutritional factors (ANF's). 
Table.1 Percent composition of experimental supplementary diets

\begin{tabular}{|l|c|c|c|c|c|c|c|}
\hline Ingredients & \multicolumn{7}{|c|}{ Experimental supplementary Diets } \\
\hline Rice bran* & $\mathbf{D}_{\mathbf{1}}$ & $\mathbf{D}_{\mathbf{2}}$ & $\mathbf{D}_{\mathbf{3}}$ & $\mathbf{D}_{\mathbf{4}}$ & $\mathbf{D}_{\mathbf{5}}$ & $\mathbf{D}_{\mathbf{6}}$ & $\mathbf{D}_{\mathbf{7}}$ \\
\hline Mustard meal* $^{*}$ & 24 & 24 & 24 & 24 & 24 & 24 & 49 \\
\hline Fish meal & 24 & 24 & 24 & 24 & 24 & 24 & 49 \\
\hline Soybean meal* & 50 & - & - & 25 & 25 & - & - \\
\hline Groundnut meal* & - & 50 & - & 25 & - & 25 & - \\
\hline
\end{tabular}

$*$ Solvent extracted; Additives in all diets: Vitamin-mineral mixture $=1.5 \%$, Salt $-0.5 \%$, Molasses $-5 \%$

Table.2 Percent Proximate composition (\%DM basis) and gross energy of different feed ingredients and prepared diets

\begin{tabular}{|c|c|c|c|c|c|c|}
\hline $\begin{array}{c}\text { Feed ingredient / } \\
\text { Feed }\end{array}$ & $\begin{array}{c}\text { Crude } \\
\text { protein }\end{array}$ & Crude fiber & Ash & $\begin{array}{c}\text { Ether } \\
\text { extract }\end{array}$ & $\begin{array}{c}\text { Nitrogen } \\
\text { free extract }\end{array}$ & $\begin{array}{c}\text { Gross Energy } \\
\text { (KCal/g) }\end{array}$ \\
\hline Rice bran & 14.88 & 23.10 & 8.60 & 0.50 & 41.32 & 2.44 \\
\hline Mustard meal & 36.58 & 24.80 & 7.50 & 1.16 & 19.66 & 2.71 \\
\hline Fish meal & 45.20 & - & 34.4 & 9 & 7.4 & 3.67 \\
\hline Soybean meal & 37.83 & 10.85 & 7.50 & 1.67 & 32.85 & 3.35 \\
\hline Groundnut meal & 31.90 & 27.30 & 8.50 & 0.83 & 21.57 & 2.53 \\
\hline $\mathbf{D}_{1}$ & 30.41 & 18.70 & 7.15 & 1.27 & 32.77 & 2.83 \\
\hline $\mathbf{D}_{2}$ & 30.88 & 12.85 & 5.95 & 1.33 & 40.59 & 3.28 \\
\hline $\mathbf{D}_{3}$ & 30.63 & 21.42 & 8.07 & 0.87 & 29.81 & 2.80 \\
\hline $\mathbf{D}_{4}$ & 30.61 & 13.45 & 7.35 & 1.83 & 36.86 & 3.14 \\
\hline $\mathbf{D}_{5}$ & 29.98 & 13.85 & 7.70 & 2.32 & 38.15 & 3.02 \\
\hline $\mathbf{D}_{6}$ & 30.89 & 16.05 & 7.98 & 1.03 & 28.25 & 2.76 \\
\hline $\mathbf{D}_{7}$ & 30.73 & 12.85 & 8.10 & 0.83 & 39.69 & 3.15 \\
\hline
\end{tabular}

Table.3 Physico-chemical parameters in different treatments

\begin{tabular}{|c|c|c|c|c|c|c|c|}
\hline Parameters & $\mathbf{D}_{1}$ & $\mathbf{D}_{2}$ & $\mathbf{D}_{3}$ & $\mathbf{D}_{4}$ & $\mathbf{D}_{5}$ & $\mathrm{D}_{6}$ & $\mathbf{D}_{7}$ \\
\hline Temperature ${ }^{0} \mathrm{C}$ & $\begin{array}{l}30.17^{\mathrm{a}} \\
\pm 0.58\end{array}$ & $\begin{array}{l}30.07^{\mathrm{a}} \\
\pm 0.56\end{array}$ & $\begin{array}{l}29.70^{\mathrm{a}} \\
\pm 0.55\end{array}$ & $\begin{array}{l}30.10^{\mathrm{a}} \\
\pm 0.55\end{array}$ & $\begin{array}{l}30.16^{\mathrm{a}} \\
\pm 0.54\end{array}$ & $\begin{array}{l}30.15^{\mathrm{a}} \\
\pm 0.55\end{array}$ & $\begin{array}{l}30.17^{\mathrm{a}} \\
\pm 0.34\end{array}$ \\
\hline $\mathrm{pH}$ & $\begin{array}{l}8.16^{\mathrm{a}} \\
\pm 0.15\end{array}$ & $\begin{array}{l}7.97^{\mathrm{a}} \\
\pm 0.15\end{array}$ & $\begin{array}{l}8.08^{\mathrm{a}} \\
\pm 0.15\end{array}$ & $\begin{array}{l}7.99^{\mathrm{a}} \\
\pm 0.13\end{array}$ & $\begin{array}{l}8.0^{\mathrm{a}} \\
\pm 0.11\end{array}$ & $\begin{array}{l}8.03^{\mathrm{a}} \\
\pm 0.12\end{array}$ & $\begin{array}{l}7.79^{\mathrm{a}} \\
\pm 0.12\end{array}$ \\
\hline DO (mg/l) & $\begin{array}{l}9.02^{\mathrm{a}} \\
\pm 1.21\end{array}$ & $\begin{array}{l}6.93^{\mathrm{a}} \\
\pm 1.66\end{array}$ & $\begin{array}{l}7.81^{\mathrm{a}} \\
\pm 1.26\end{array}$ & $\begin{array}{l}8.11^{\mathrm{a}} \\
\pm 1.40\end{array}$ & $\begin{array}{l}8.27^{\mathrm{a}} \\
\pm 1.01\end{array}$ & $\begin{array}{l}8.33^{\mathrm{a}} \\
\pm 1.33\end{array}$ & $\begin{array}{l}7.39^{\mathrm{a}} \\
\pm 1.63\end{array}$ \\
\hline $\begin{array}{l}\text { Total Alkalinity } \\
\text { (mg/l) }\end{array}$ & $\begin{array}{l}261.63^{\mathrm{a}} \\
\pm 14.07\end{array}$ & $\begin{array}{l}251.81^{\mathrm{a}} \\
\pm 18.93\end{array}$ & $\begin{array}{l}264.31^{\mathrm{a}} \\
\pm 16.44\end{array}$ & $\begin{array}{l}253.59^{\mathrm{a}} \\
\pm 21.59\end{array}$ & $\begin{array}{l}276.90^{\mathrm{a}} \\
\pm 20.75\end{array}$ & $\begin{array}{l}292.04^{\mathrm{a}} \\
\pm 18.34\end{array}$ & $\begin{array}{l}248.63^{\mathrm{a}} \\
\pm 18.90\end{array}$ \\
\hline Hardness (mg/l) & $\begin{array}{l}231.45^{\mathrm{a}} \\
\pm 11.69\end{array}$ & $\begin{array}{l}212.54^{\mathrm{a}} \\
\pm 15.49\end{array}$ & $\begin{array}{l}217.63^{\mathrm{a}} \\
\pm 17.51\end{array}$ & $\begin{array}{l}209.63^{\mathrm{a}} \\
\pm 16.52\end{array}$ & $\begin{array}{l}224.36^{\mathrm{a}} \\
\pm 17.77\end{array}$ & $\begin{array}{l}238.81^{\mathrm{a}} \\
\pm 22.33\end{array}$ & $\begin{array}{l}224.00^{\mathrm{a}} \\
\pm 19.68\end{array}$ \\
\hline Ammonia (mg/l) & $\begin{array}{l}0.18^{\mathrm{a}} \\
\pm 0.06\end{array}$ & $\begin{array}{l}0.10^{\mathrm{a}} \\
\pm 0.03\end{array}$ & $\begin{array}{l}0.18^{\mathrm{a}} \\
\pm 0.04\end{array}$ & $\begin{array}{l}0.13^{\mathrm{a}} \\
\pm 0.04\end{array}$ & $\begin{array}{l}0.12^{\mathrm{a}} \\
\pm 0.03\end{array}$ & $\begin{array}{l}0.16^{\mathrm{a}} \\
\pm 0.05\end{array}$ & $\begin{array}{l}0.18^{\mathrm{a}} \\
\pm 0.07\end{array}$ \\
\hline Phosphate (mg/l) & $\begin{array}{l}0.28^{\mathrm{a}} \\
\pm 0.07\end{array}$ & $\begin{array}{l}0.30^{\mathrm{a}} \\
\pm 0.06\end{array}$ & $\begin{array}{l}0.20^{\mathrm{a}} \\
\pm 0.04\end{array}$ & $\begin{array}{l}0.22^{\mathrm{a}} \\
\pm 0.07\end{array}$ & $\begin{array}{l}0.19^{\mathrm{a}} \\
\pm 0.04\end{array}$ & $\begin{array}{l}0.19^{\mathrm{a}} \\
\pm 0.09\end{array}$ & $\begin{array}{l}0.28^{\mathrm{a}} \\
\pm 0.08\end{array}$ \\
\hline Nitrite - $\mathrm{NO}_{2}(\mathrm{mg} / \mathrm{l})$ & $\begin{array}{l}0.022^{\mathrm{a}} \\
\pm 0.015\end{array}$ & $\begin{array}{l}0.021^{\mathrm{a}} \\
\pm 0.002\end{array}$ & $\begin{array}{l}0.025^{\mathrm{a}} \\
\pm 0.003\end{array}$ & $\begin{array}{l}0.025^{\mathrm{a}} \\
\pm 0.008\end{array}$ & $\begin{array}{l}0.022^{\mathrm{a}} \\
\pm 0.004\end{array}$ & $\begin{array}{l}0.027^{\mathrm{a}} \\
\pm 0.029\end{array}$ & $\begin{array}{l}0.033^{\mathrm{a}} \\
\pm 0.003\end{array}$ \\
\hline Nitrate $-\mathrm{NO}_{3}(\mathrm{mg} / \mathrm{l})$ & $\begin{array}{l}0.16^{\mathrm{a}} \\
\pm 0.49\end{array}$ & $\begin{array}{l}0.23^{\mathrm{a}} \\
\pm 0.89\end{array}$ & $\begin{array}{l}0.13^{\mathrm{a}} \\
\pm 0.04\end{array}$ & $\begin{array}{l}0.23^{\mathrm{a}} \\
\pm 0.07\end{array}$ & $\begin{array}{l}0.16^{\mathrm{a}} \\
\pm 0.04\end{array}$ & $\begin{array}{l}0.17^{\mathrm{a}} \\
\pm 0.04\end{array}$ & $\begin{array}{l}0.21^{\mathrm{a}} \\
\pm 0.08\end{array}$ \\
\hline
\end{tabular}

Values are Mean \pm Standard Deviation 
Table.4 Growth parameters and economic evaluation of different treatments at the end of the experiment

\begin{tabular}{|c|c|c|c|c|c|c|c|}
\hline Parameters & $\mathrm{D}_{1}$ & $\mathbf{D}_{2}$ & $\mathbf{D}_{3}$ & $\mathbf{D}_{4}$ & $\mathbf{D}_{5}$ & $\mathrm{D}_{6}$ & $\mathrm{D}_{7}$ \\
\hline $\begin{array}{l}\text { Average final body } \\
\text { weight (g) }\end{array}$ & $\begin{array}{l}17.21^{\mathrm{ab}} \\
\pm 1.12\end{array}$ & $\begin{array}{l}23.92^{\mathrm{a}} \\
\pm 0.80\end{array}$ & $\begin{array}{l}16.80^{\mathrm{b}} \\
\pm 1.92\end{array}$ & $\begin{array}{l}20.88^{\mathrm{a}} \\
\pm 1.34\end{array}$ & $\begin{array}{c}19.33^{\mathrm{ab}} \\
\pm 1.17\end{array}$ & $\begin{array}{l}15.88^{\mathrm{b}} \\
\pm 1.90\end{array}$ & $\begin{array}{l}18.58^{\mathrm{ab}} \\
\pm 1.52\end{array}$ \\
\hline$\% \mathrm{WG}$ & 102.11 & 169.67 & 104.13 & 135.40 & 125.55 & 85.73 & 115.29 \\
\hline SGR & 0.46 & 0.66 & 0.47 & 0.57 & 0.54 & 0.41 & 0.51 \\
\hline FCR & 16.72 & 10.08 & 17.69 & 11.34 & 15.84 & 20.24 & 12.59 \\
\hline $\begin{array}{l}\text { PER } \\
\end{array}$ & 0.25 & 0.32 & 0.18 & 0.30 & 0.24 & 0.15 & 0.29 \\
\hline Condition factor $\mathbf{K}$ & 0.60 & 0.67 & 0.60 & 0.64 & 0.62 & 0.59 & 0.64 \\
\hline $\begin{array}{c}\text { Total fish biomass } \\
\text { harvested (g) }\end{array}$ & 344.2 & $\begin{array}{c}478.4 \\
(+38.98)\end{array}$ & $\begin{array}{c}336 \\
(-2.38)\end{array}$ & $\begin{array}{c}417.6 \\
(+21.32)\end{array}$ & $\begin{array}{c}386.6 \\
(+12.32)\end{array}$ & $\begin{array}{c}317.6 \\
(-7.72)\end{array}$ & $\begin{array}{c}371.6 \\
(+7.96)\end{array}$ \\
\hline Return(@ 200/kg) & 68.8 & 95.6 & 67.2 & 83.4 & 77.2 & 63.4 & 74.2 \\
\hline Total feed given (kg) & 1.457 & 1.518 & 1.516 & 1.362 & 1.704 & 1.484 & 1.253 \\
\hline Feed cost/ Kg (') & 20.4 & 25.6 & 22.1 & 22.85 & 20.8 & 23.85 & 14.9 \\
\hline Total feed cost ( ) & 29.73 & $\begin{array}{c}38.86 \\
(+30.70)\end{array}$ & $\begin{array}{c}33.51 \\
(+12.71)\end{array}$ & $\begin{array}{l}31.12 \\
(+4.6)\end{array}$ & $\begin{array}{c}49.10 \\
(+65.15)\end{array}$ & $\begin{array}{c}35.39 \\
(+19.04)\end{array}$ & $\begin{array}{c}18.66 \\
(-37.24)\end{array}$ \\
\hline Net & 39.07 & $\begin{array}{c}56.74 \\
(+45.23)\end{array}$ & $\begin{array}{c}33.69 \\
(-13.77)\end{array}$ & $\begin{array}{c}52.28 \\
(+33.81)\end{array}$ & $\begin{array}{c}28.10 \\
(-28.07)\end{array}$ & $\begin{array}{c}28.01 \\
(-28.31)\end{array}$ & $\begin{array}{c}55.54 \\
(+42.15)\end{array}$ \\
\hline
\end{tabular}

Fig.1A-1G Cluster analysis of log transformed correlation matrix data of physico-chemical parameters of experimental diets $\left(\mathrm{d}_{1}-\mathrm{d}_{7}\right)$

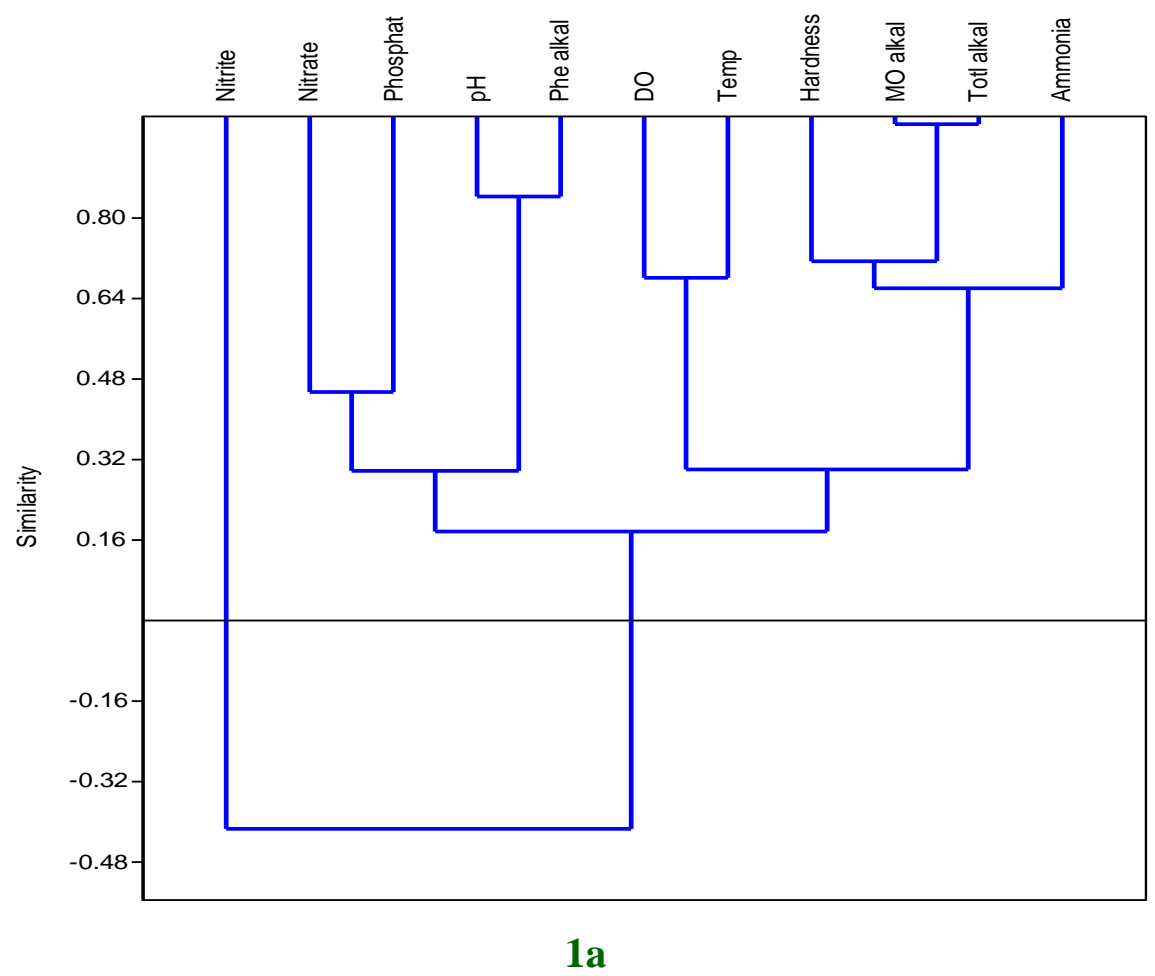


Int.J.Curr.Microbiol.App.Sci (2018) 7(6): 734-746

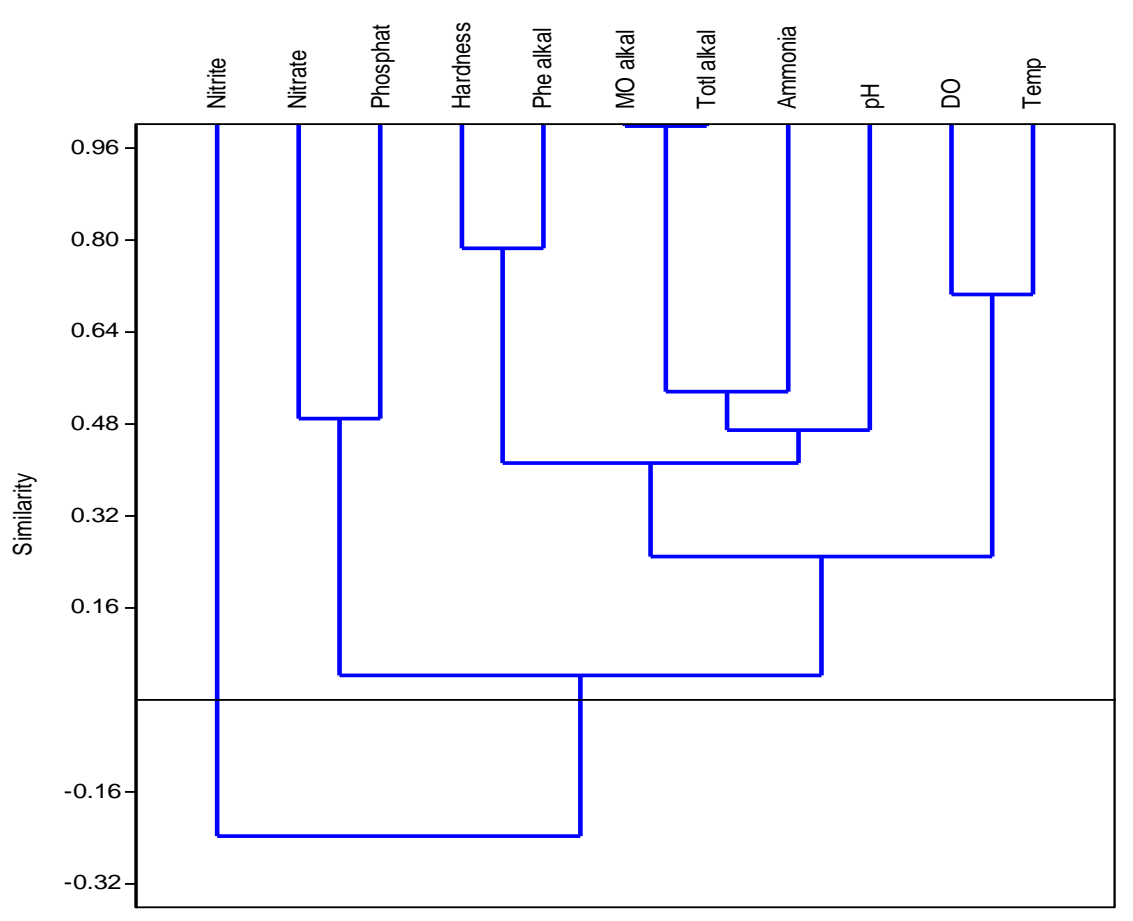

1b

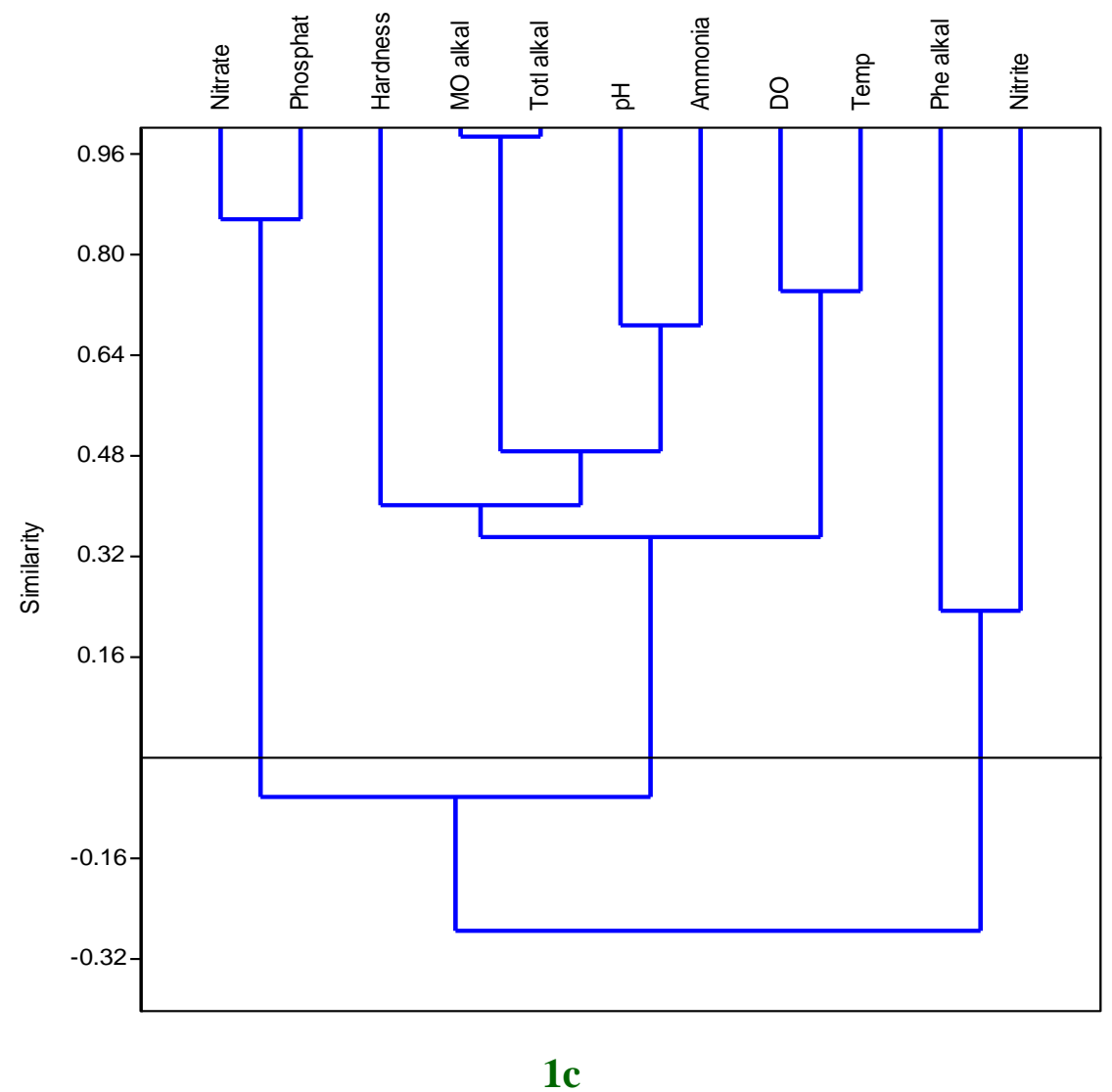


Int.J.Curr.Microbiol.App.Sci (2018) 7(6): 734-746

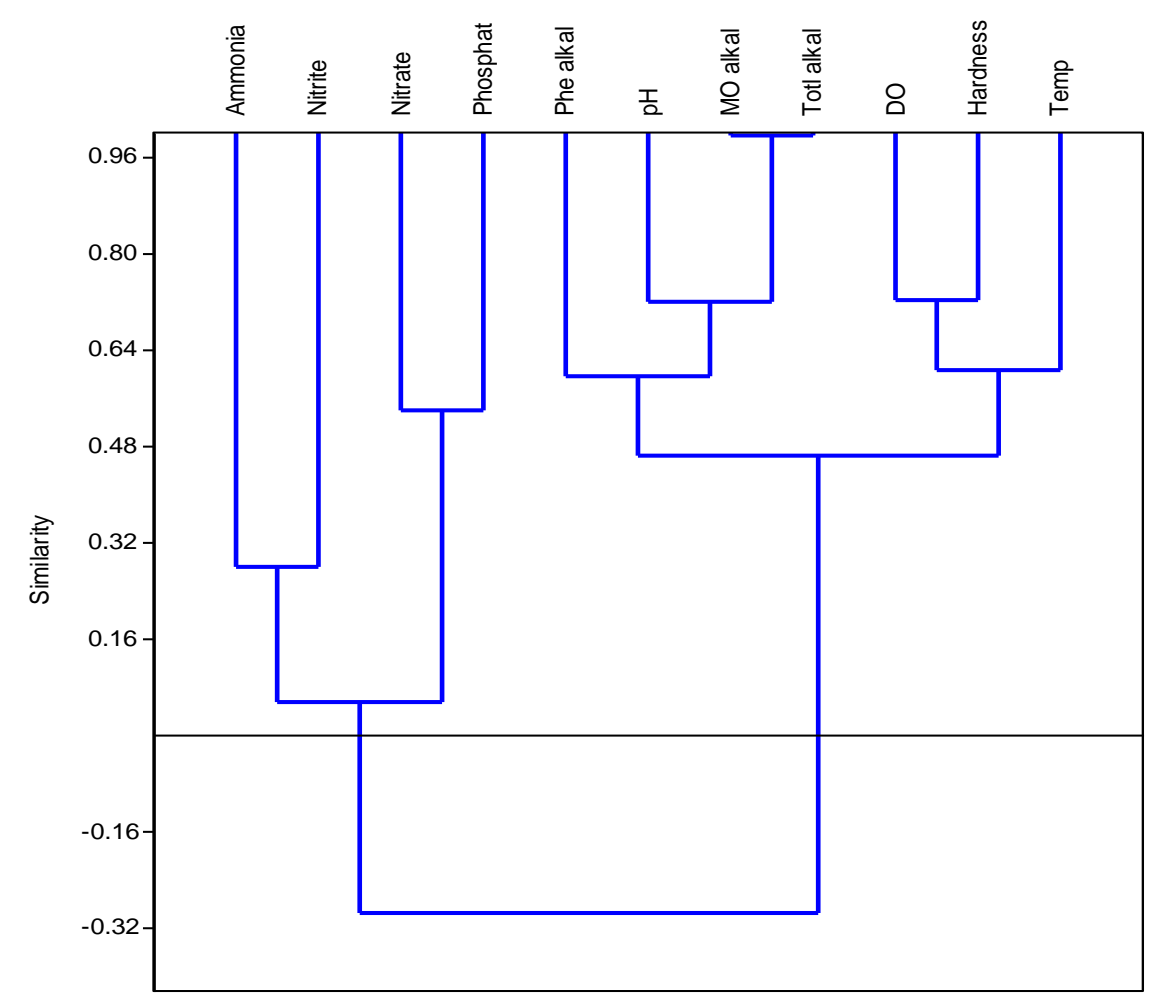

1d

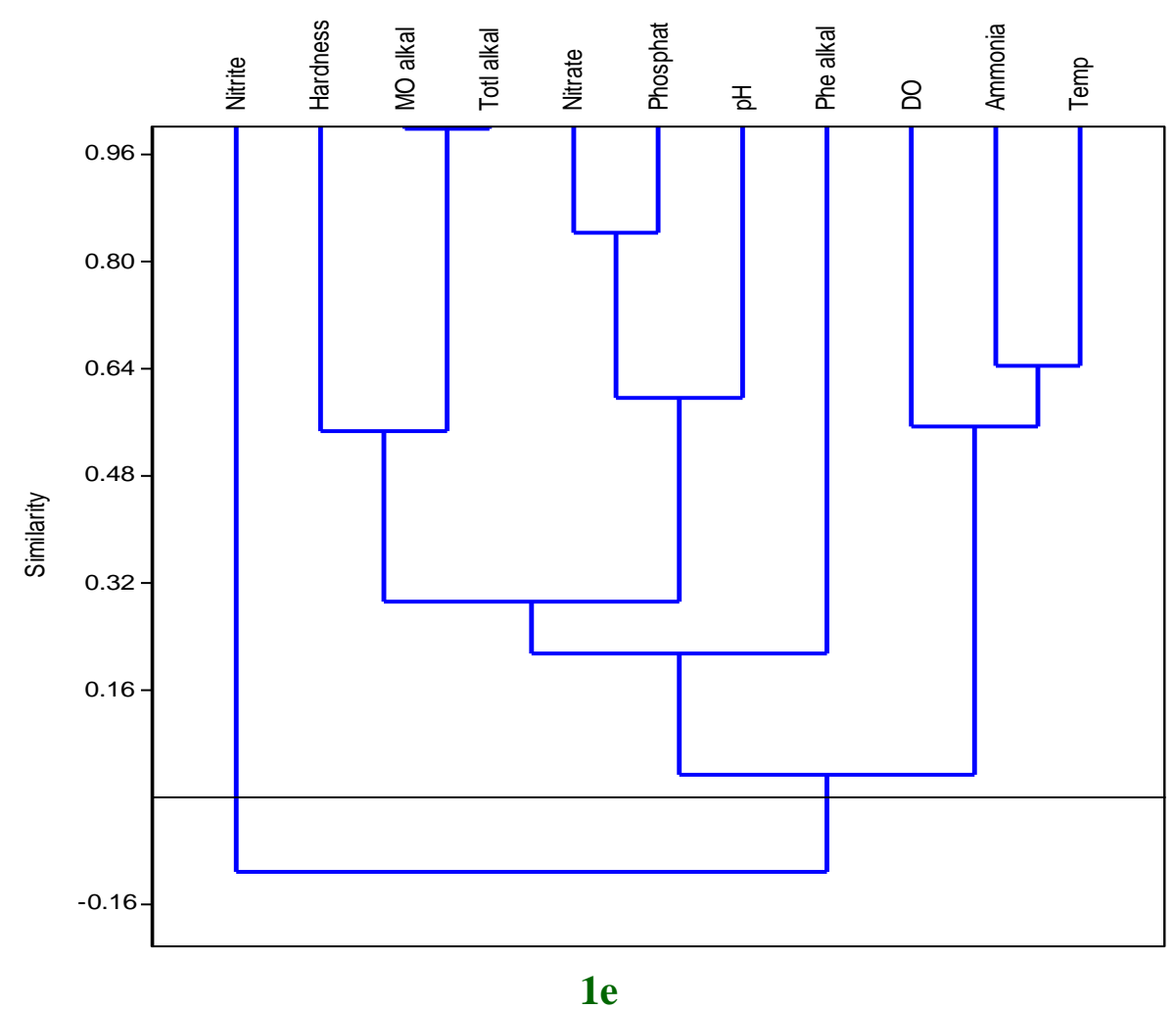


Int.J.Curr.Microbiol.App.Sci (2018) 7(6): 734-746
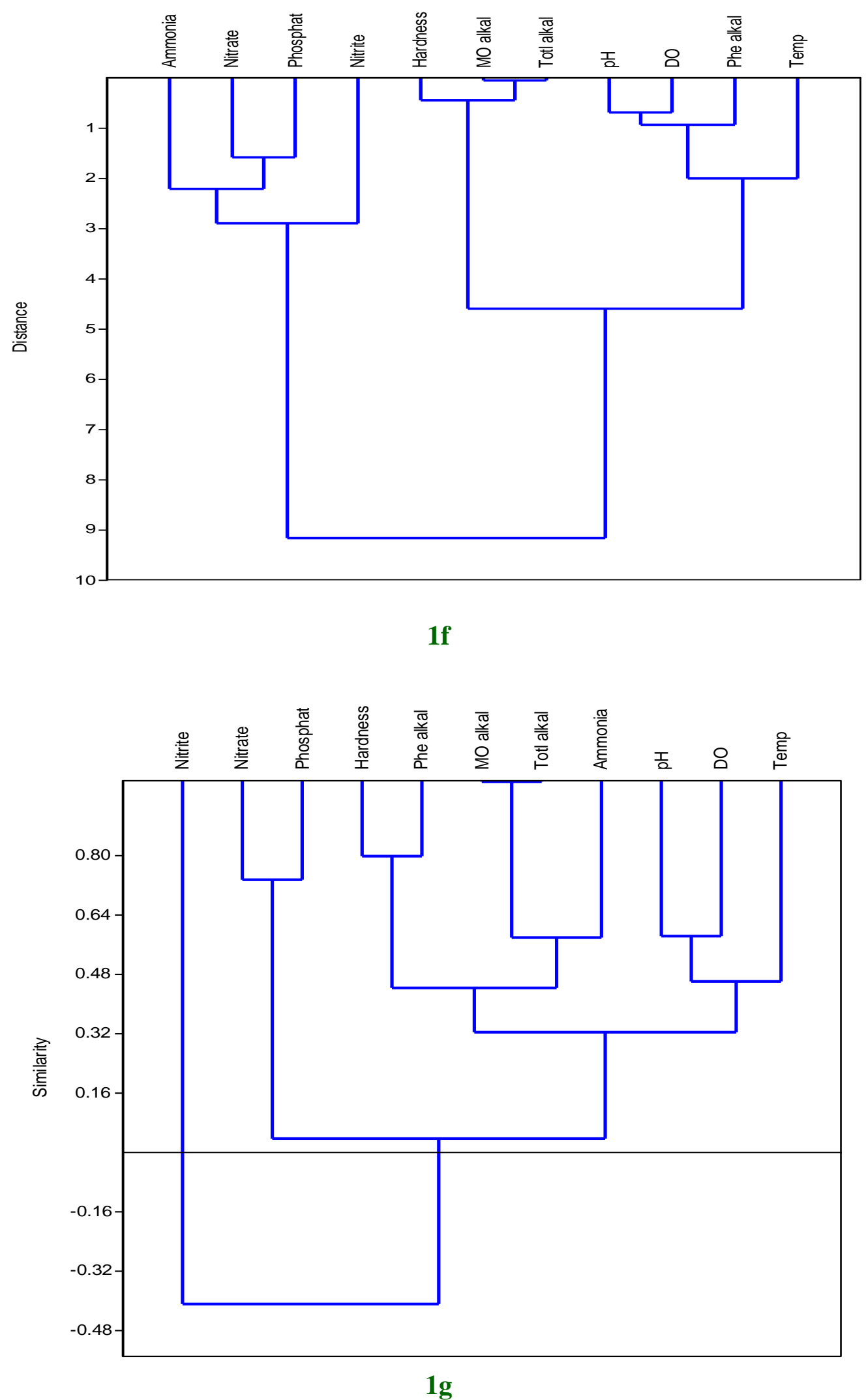
Groundnut meal (GNM) showed acceptability up to $50 \%\left(\mathrm{D}_{5}\right)$ in place of fish meal (rich in lysine and methionine) and growth parameters get deteriorated when it was included at $100 \%$ $\left(D_{3}\right)$ level in place of fish meal. Nguyen and Davis (2009) reported that combining groundnut meal with some other plant protein ingredients can result in growth enhancement, but in present study diet $\mathrm{D}_{6}$ having combination of SBM and GNM (in place of fishmeal) does not give encouraging results. Similar results were observed by Akhand et al., (1989) in $H$. fossilis. Although GNM incorporated diets i.e. diet $\mathrm{D}_{6}(\mathrm{CP}-30.89 \%)$ containing GNM and SBM and diet $\mathrm{D}_{3}(\mathrm{CP}-$ $30.63 \%$ ) containing only GNM had optimum protein level, but these diets does not show encouraging results, which may be due to the deficiency of sulphur containing amino acids i.e. methionine and cystiene followed by lysine (Jauncey, 1998) along with deficient amount of vitamin $B_{12}$ and calcium in groundnut meal. In the study conducted by Jackson et al., (1982) for tilapia, Sarotherodon mossambicus, groundnut cake can replace $25 \%$ of fish meal, but growth rate decreases at higher incorporation levels. Similar results were observed in present study as diet containing $50 \%$ of GNM in place of fish meal $\left(\mathrm{D}_{5}\right)$ performed better than diet containing $100 \%$ groundnut in place of fish meal $\left(\mathrm{D}_{3}\right)$. Combining GNM with fish meal (rich in methionine and lysine) resulted in nutritive feed in terms of amino acid composition (Ovie and Ovie, 2007). Agbo et al., (2011) also found in their study that groundnut cake can replace $50 \%$ of fish meal protein without adversely affecting growth, feed efficiency, whole body composition and nutrient digestibility in tilapia (O. niloticus) fingerlings. The low feed intake, feed utilization and poor palatability of $\mathrm{D}_{3}$ and $\mathrm{D}_{6}$ (due to the deficiency of essential amino acids like methionine and lysine) might have resulted in low growth performance in $H$. fossilis in present study

\section{Condition factor (K)}

The maximum value of condition factor ' $\mathrm{K}$ ' was recorded (Table 4) in diet $\mathrm{D}_{2}(0.67)$ followed by $\mathrm{D}_{4}$ and $\mathrm{D}_{7}(0.64), \mathrm{D}_{5}(0.62), \mathrm{D}_{1}$ and $\mathrm{D}_{3}(0.60)$, and $\mathrm{D}_{6}(0.59)$. The values of ' $K$ ' in $D_{2}, D_{4}$, and $D_{7}$ were higher than control $\left(\mathrm{D}_{1}\right)$, suggesting that fish fed with diet containing SBM in place of fish meal and diet without fish meal were much more robust than the fish fed with control diet.

The condition factor $(K)$ of a fish reflects physical and biological characteristics and fluctuations by interaction among feeding conditions, parasitic infections and physiological factors (Le Cren, 1951) along with assessment of fish condition (Lambert and Dutil, 1997) based on weight at a given length (indicating energy reserves in fish). Moreover, body condition provides an alternative to the expensive in vitro proximate analysis of tissues (Sutton et al., 2000).

Therefore, information on condition factor can be vital to culture system management because they provide the producer with information of the specific condition under which organisms are developing (Araneda et al., 2008). Higher condition factor in $\mathrm{D}_{2}$ (0.67) under culture environment indicates the suitability of diet for the experimental fish for culture (Khan et al., 2012; Kumar et al., 2013).

\section{Economic evaluation of different diets used for the experiment}

Among different treatments, highest fish biomass $(478.4 \mathrm{~g})$ was recorded for diet $\mathrm{D}_{2}$ followed by $\mathrm{D}_{4}(417.6 \mathrm{~g}), \mathrm{D}_{5}(386.6 \mathrm{~g}), \mathrm{D}_{7}$ (371.6 g), $\mathrm{D}_{1}(344.2 \mathrm{~g}), \mathrm{D}_{3}(336.0 \mathrm{~g})$ and $\mathrm{D}_{6}$ (317.6 g). Maximum net profit with respect to total biomass harvested and feed cost reduction was recorded for $\mathrm{D}_{2}$, which was $45.23 \%$ higher than control $\left(\mathrm{D}_{1}\right)$ followed by 
$\mathrm{D}_{7}(42.15 \%)$ and $\mathrm{D}_{4}(33.81 \%)$, whereas it was lower for all the other diets.

Present study clearly demonstrates $100 \%$ replacement of fish meal with soybean meal in catfish culture for formulating nutritionally balanced high quality diet. In present study, CP content $(23.76 \%)$ of the fish meal used was less than the mustard meal $(36.58 \%)$ and two of the experimental ingredients i.e. soybean meal $(37.83 \%)$ and groundnut meal (31.90\%), due to which it can't support the fish growth as a protein ingredients. Further, diet $\mathrm{D}_{7}$ (traditional carp diet used by farmers) also gave better results than control diet $\left(D_{1}\right)$ having fish meal as major protein source. Hence, it can be concluded in view of deteriorated quality of fish meal, soybean meal can be one of the most promising plant protein ingredient for catfish species like Heteropnuestes fossilis.

\section{Conflict of interest}

The authors declare that there are no conflicts of interest.

\section{Acknowledgements}

Authors are thankful to Indian Council of Agricultural Research (ICAR) for providing necessary financial assistance under the project "Inland Aquaculture in Punjab" (Niche Area of Excellence). Thanks are also due to the Dean, College of Fisheries, GADVASU, Ludhiana, Punjab, India for providing necessary research facilities.

\section{References}

Agbo, N.W., Adjei-Boateng, D. and Jauncey, K. (2011) The Potential of Groundnut (Arachis hypogaea L.) By-Products as Alternative Protein Sources in the Diet of Nile Tilapia (Oreochromis niloticus). Journal of Applied Aquaculture, 23, 367378.
Akhand, A.M., Miah, M.I. and Haque, M.M. (1989) Effect of dietary protein level on growth, feed conversion and body composition of Singhi (Heteropneustes fossilis Bloch). Aquaculture, 77, 175-180.

AOAC (Association of Official Analytical Chemists). (2005) Official methods of analysis of Association of official analytical chemists International. 16th edn. Arlington, Virginia, USA.

APHA. (1991) Standard methods for the examination of water and wastewater. $18^{\text {th }}$ ed., American Public Health Association, DC.

Araneda, M., Perez, E.P. and Gasca, L.E. (2008) White shrimp Penaeus vannamei culture in freshwater at three densities: Condition state based on length and weight. Aquaculture, 283, 13-18.

Bhilave, M.P., Bhosale, S.V. and Nadaf, S.B. (2012) Protein Efficiency Ratio (PER) of Ctenopharengodon idella fed on soyabean formualted feed. Biological Forum: An International Journal, 4 (1), $79-81$.

Boyd, C.E. and Pillai, Y.K. (1984) Water quality management in aquaculture. CMFRI Special Publlcation, 22, 97.

Boyd, C.E. and Tucker, C.S. (1998) Pond aquaculture water quality management. Kluwer Academic Pulishers, Boston, London.

Brett, J.R. (1979) Environmental factors and growth. In: Hoar W S, Randal D J, Brett J R. (Eds.) Environmental relations and behavior, Fish Physiology 6. Academic press, New York. pp 599-677.

Dehadrai, P.V. (1978) Forth workshop report of all India coordinated research project on Air-breathing fish culture at Central Inland Fisheries Research Institute. Barrackpur, December 12-13, 1978.

Dhawan, A. and Kaur, V.I. (2007) Effect of alternate protein supplements on the performance of Clarias batrachus. Indian Journal of Animal Nutrition, 24, 175-178.

Eyo, A.A. and Olatunde A.A. (1998) Effect of supplementation of soya bean diet with $\mathrm{L}$ and L-methionine on the growth of 
mudfish $C$. auguillaris fingerlings. Nigeria Journal of Biotechnology, 9 (1) 9-16.

FAO. 2012. World review of Fisheries and Aquaculture. The state of world fisheries and aquaculture. pp 3-147.

Goda, A.M., El, A.S., Haroun, E.R. and Chowdhury M.A. (2007) Effect of totally or partially replacing of fish meal by alternative protein sources on growth of African catfish Clarias gariepinus (Burchell, 1822) reared in concrete tanks. Aquaculture Research, 38 (3), 279-287.

Haniffa, M.A. (2009) Native catfish culture-a technology package for fish farmers. Aquaculture Asia, 15, 22-24.

Htun-Han, M. (1978) The reproductive biology of the dab Limanda limanada (L.) in the North Sea: gonadosomatic index, hepatosomatic index and condition factor. Journal Fish Biology, 13 (1), 351-377.

Jackson, A.J., Capper, B.S. and Matty A.J. (1982) Evaluation of some plant protein in complete diets for the tilapia Sarotherodon mossambicus. Aquaculture, 27, 97-109.

Jauncey, K. (Editor). (1998) Tilapia feeds and feeding. Stirling, UK. Pisces Press. UK.

Kaushik, S.J., Cravedi, J.P., Lalles, J.P., Sumpter, J., Fauconneau, B. and Laroche, M. (1995) Partial or total replacement of fish meal by soya protein on growth, protein utilization, potential estrogenic or antigenic effects, cholesterolemia and flesh quality in rainbow trout. Aquaculture, 133, 257-274.

Khan, M.A. and Jafri, A.K. 1990. On the dietary protein requirement of Clarias batrachus (Linnaeus). Journal of Aquaculture in the Tropics, 5, 191-198.

Khan, M.A., Khan, S. and Miyan, K. 2012. Length-weight relationship of giant snakehead, Channa maurulius and stinging catfish, Heteropneustes fossilis from the River Ganga, India. Journal of Appllied Ichthyology, 28, 154-155.

Kumar, K., Lalrinsanga, P.L., Sahoo, M., Mohanty, U.L., Kumar, R. and Sahu, A.K. (2013) Length-weight Relationship and Condition Factor of Anabas testudineus and Channa Species under Different Culture Systems. World Journal of Fish Marine Science, 5 (1), 74-78.

Lambert, Y. and Dutil, J.D. (1997) Can simple condition indices be used to monitor and quantify seasonal changes in the energy reserves of Atlantic cod (Gadus morhua). Canada Journal of Fisheries and Aquaculture Science, 54 (1), 104-112.

Le Cren, E.D. (1951) The length-weight relationships and seasonal cycle in gonad weight and condition in the perch (Perca fluviatilis). Journal of Animal Ecology, 20, 201-19.

Li, M.H., Robinson, E.H. and Hardy, R.W. (2000) Protein sources for feed. In Encyclopedia of Aquaculture. $\mathrm{R} \mathrm{R}$ Stickney (Ed.). New York. NY: John Wiley \& Sons Inc. pp. 688-695.

Lim, C., and Akiyama, D. (1992) Full fat utilization of Soybean meal by fish. Asian Fisheries Science, 5, 181-197.

Lovell, T. (Editor). (1989) Nutrition and feeding of fish. An AVI book. Published by Van Nostrand Reinhold, New York, USA.

Mohsen, A.A. and Lovell, R.T. (1990) Partial substitution of soybean meal with animal protein sources in diets for channel catfish. Aquaculture, 90, 303-311.

Nguyen, T.N. and Davis, D.A. (2009) Evaluation of Alternative Protein Sources to Replace Fish Meal in Practical Diets for Juvenile Tilapia, Oreochromis spp. Journal of the World Aquaculture Society, 40 (1), 113-121.

NRC. (1993) National research Council. Nutrient Requirements of Fish. National Academy Press, Washington, DC. pp. 114.

Nyirenda, J., Mwabumba, M., Kaunda, E. and Sales, J. (2000) Effect of substituting animal protein sources with soybean meal in diets of Oncorhynchus karongae (Trewavas 1941). Naga: The ICLARM Quarterly. 23(4). OctoberDecember. 
Ollie, J.J., Krogdahl, A. and Hjelmeland, K. (1994) Soybean trypsin inhibitors in diets for Atlantic salmon (Slmo salar) effects on nutrient digestibilities and trypsin in pyloric caeca homogenate and intestinal content. Comparative Biochemistry and Physiology A, 109, 923-928.

Ovie, S. and Ovie, S. (2007) The effect of replacing fish meal with $10 \%$ of groundnut cake in the diets of $H$. longlifilis on its growth, food conversion and survival. Journal of Applied Science and Environment Sciences, 11, 87-90.

Pillay, T.V.R. (Editor). (2001) Aquaculture principles and Practices. Blackwell science Ltd. Oxford.

Rahman, M.S., Chowdhury, M.Y., Haque, M.A. and Haq, M.S. (1982) Limnological studies of four ponds. Bangladesh Journal of Fisherie,s 2-5 (1-2), 25-35

Reigh, R.C. (1999) Production characteristics of pond-raised channel catfish Ictalurus punctatus fed diets with and without animal protein for three growing seasons. Journal World Aquaculture Society, 30, 154-160.

Robinson, E.H. and Li, M.H. (1999) A practical guide to nutrition, feeds and feeding of catfish. Mississippi Agricultural and Forestry Experiment Station Bulletin 1041.

Robinson, E.H. and Li, M.H. (2007) Catfish protein nutrition revised. Mississippi State University Bulletin 1159. pp 1-13.
Robinson, E.H., Li M.H. and Houge, C.D. (2000) Catfish nutrition: feed. Publication 2413. Mississippi State University Extension service.

Robinson, E.H., Li, M.H. and Houge, C.D. (2006) Comparison of practical diets with and without animal protein at various concentrations of dietary protein on performance of channel catfish Ictalurus punctatus raised in earthen ponds. Journal of the World Aquaculture Society, 29, 273-280.

Rowland, S.J. (1986) Site selection, design and operation of aquaculture farms In: Owen P, Bowden J (Ed.) Freshwater aquaculture in Australia, Brisbane, $1^{\text {st }}$ edition. Rural Press Queensland, Australia.

Sharma, A.P., Singh, U.P. and Archana, S. (2001) Sustainable Development of fish farming. Indian farmers' Digest, 34, 137143.

Sutton, S.G., Bult, T.P. and Haedrich, R.L. (2000) Relationships among fat weight, body weight, water weight and condition factors in wild Atlantic salmon parr. Trasections American Fisheries Society, 129, 527-538.

Webster, C.D., Yance, D.H. and Tidwell J.H. (1992) Effect of partially or totally replacing fish meal with soybean meal on growth of blue catfish (Ictalurus furcatus). Aquaculture, 103, 141-152.

\section{How to cite this article:}

Archit Shukla, Vaneet Inder Kaur, Pankaj Kumar, Meera D. Ansal, Asha Dhawan and Varun Mishra. 2018. Utilization of Dietary Soybean Meal and Groundnut Meal as Fish Meal Replacement in Heteropnuestes fossilis (Bloch.). Int.J.Curr.Microbiol.App.Sci. 7(06): 734-746. doi: https://doi.org/10.20546/ijcmas.2018.706.086 